\title{
Different Approaches to the National Management of Rainwater
}

\section{Rozdílné př́stupy států k hospodaření s deštovými vodami}

Nina Ličková, xalickova@stud.fa.vutbr.cz

Ústav urbanismu, Fakulta architektury, Vysoké učení technické v Brně školitel: doc. Ing. arch. Karel Havliš

\begin{abstract}
The text deals with the application of rainwater management systems (Rainwater harvestin, in text as RWH) and their application within cities and municipalities. It solves the problem of how to use these principles by the general public in private real estate, architects and planners in public spaces and buildings. Some of the tools are implications for legislation, disseminating HDV information, education, introducing awareness and creating motivation to use RWH systems. Several countries were selected in Europe and overseas, for example, to compare individual approaches to promoting and deploying RWH. The aim is to get an overview of the possibilities of the state and the cities to support the development of the idea of proper management of rainwater.
\end{abstract}

KEYWORDS: rainwater; global changes; legislation

\begin{abstract}
ABSTRAKT: Text se zabývá otázkou aplikace systémů hospodaření s deštovými vodami (dále jen HDV) a jejich aplikace v rámci měst a obcí v různých zemích světa. Zabývá se problémem, jak dosáhnout užívání vhodných a možných principů širokou veřejností u soukromých nemovitostí, architekty a plánovači u veřejných prostranství a budov. Mezi nástroje, jimiž toho lze docílit, patř́i: implementace do legislativy, rozšiřování informací o HDV, vzdělávání, zvyšování všeobecného povědomí (o HDV) a vytváření motivace $\mathrm{k}$ užívání systémů HDV. Bylo vybráno několik zemí v Evropě i zámoří, na jejichž prríkladu bude možné porovnat jednotlivé prŕistupy $\mathrm{k}$ propagaci a zavádění HDV. Cílem je získat přehled o možnostech států a měst, jak podpořit rozvoj idey správného nakládání s deštovými vodami.
\end{abstract}


KLÍČOVÁ SLOVA: deštová voda; globální změny; legislativa

\section{1. Úvodní slovo}

Hlavní ideou př́spěvku je připomenutí, že problém bilance hospodaření s deštovými vodami je nutno vnímat jako globální. Jedná se o reflexi, pomocí které lze zpomalit dopady klimatických a jiných změn.

Historické prríklady ze starověku ukazují, že se civilizace, především v suchých oblastech, zabývaly aktivně sběrem srážkových vod, které pro ně byly alespoň parciálním zdrojem, a nakládáním s nimi. Zánik těchto starověkých civilizací a jejich kultury a príchod středověku, novověku, průmyslové revoluce a novodobé společnosti uzavřely očekávatelný dějinný kruh. S příchodem myšlenek ekologie po spoušti průmyslové revoluce se objevuje i idea péče o prŕrodní zdroje a hospodaření s nimi.

\subsection{Světové povědomí o HDV}

Význam i váha hospodaření s deštovými vodami závratně rostou s postupující globalizací. Tuto problematiku aktivně řeší světové organizace. Jejich poučování a apely na jednotlivé státní struktury však, zdá se, nemají takovou váhu. Každá země je svrchovaná a nakládá s vodohospodářskými zásadami dle svého úsudku.

Přístupy jednotlivých států jsou velmi rozdílné, třeba i u států patřících do jedné federace.

\subsection{Globální změny a vodní krize}

V úvodu si dovolím demonstrovat několik faktů zachycujících skutečnost probíhajících změn a nezbytnost podpory hospodaření s prírodními zdroji, tedy i s deštovými vodami. Jedná se především o demografické změny - neustálý růst počtu obyvatel a devastace př́rodních zdrojů. Planeta má omezenou kapacitu a omezený potenciál ve smyslu obživy jejích obyvatel. Ve velké míře roste urbanizace (především v rozvojových zemích), tedy proces, kdy přichází vesnické obyvatelstvo do měst za prací. Města rostou matematickou řadou, okolní oblasti se vylidňují. Probíhají klimatické změny jako zvyšování průměrné teploty, snižování množství srážek, proměna charakteru srážek a klimatické změny apod.

Rychlý růst populace v kombinaci s industrializací, urbanizací, rozvojem zemědělství 
a intenzivním životním stylem vede k celosvětové vodní krizi. Zhruba $20 \%$ obyvatel $\mathrm{v}$ současnosti nemá př́stup $\mathrm{k}$ bezpečné pitné vodě.

Kontaminace pitné vody a znečištění dusičnany a těžkými kovy z řek, jezer a nádrží jsou běžnými problémy na celém světě. Kapacitu světových zásob sladké vody již nelze zvýšit.

Bezpečnost vod, stejně jako zabezpečení potravin, se v mnoha oblastech světa stává významnou národní a regionální prioritou.

\subsection{Důsledky a východiska}

Vzhledem k tomu, že mnoho prrírodních zdrojů (např. voda, půda, lesy a populace živočichů a ryb) se již v některých oblastech využívá nad rámec jejich limitů, bude nutné vynaložit značné úsilí, aby bylo možné $\mathrm{v}$ př́šších padesáti letech uspokojit potřeby dalších tří miliard lidí.

Realizace idey udržitelného rozvoje, navazující na zachování přírodních zdrojů, je v dnešní době dosažitelným cílem, avšak pouze ve vyspělých zemích. Rozvojové lokality, ač v nich žije největší procento lidské populace, snahy o udržitelnost nenaplňují.

K významným krokům a prioritám na cestě k udržitelnému rozvoji patří hospodaření $s$ deštovými vodami. Systémy pro sběr deštové vody mohou poskytovat vodu v místě, kde je potřeba. Tato metoda minimalizuje negativní dopady na životní prostředí. Ve srovnání s jinými technologiemi pro rozvoj vodních zdrojů tato metoda minimalizuje negativní dopady na životní prostředí. Deštová voda je poměrně čistá. Svým složením se blíží vodě destilované. Fyzikální a chemické vlastnosti deštové vody jsou obvykle nadřazeny vlastnostem zdrojů podzemních vod, které mohou být znečištěny.

Následující kapitoly se zaměří na legislativní a organizační rámec nakládání s deštovými vodami iniciovaný nadnárodními organizacemi. Následně se text bude zabývat podmínkami HDV ve vybraných zemích.

\section{Nadnárodní organizace}

\subsection{OSN}

Organizace spojených národů zahrnuje nejvíce zemí světa. Je to nadnárodní organizace, která také usiluje o dodržování lidských práv a s nimi spojený udržitelný rozvoj. 
Ve smyslu základních lidských práv má každý člověk na Zemi právo na pitnou vodu. $\mathrm{V}$ tomto směru narážíme na velký problém s rostoucím počtem obyvatel a dnešními zásobami prŕrodních zdrojů, tedy i pitné vody na Zemi. Již dnes není možné zajistit pitnou vodu veškeré populaci.

\subsection{UNEP - United Nations Environment Programme}

OSN tento problém předvídá a v roce 1972 v keňském Nairobi vyhlašuje Program pro životní prostředí (United Nations Environment Programme). UNEP odpovídá za environmentální stránku udržitelného rozvoje a její propojení s ekonomickou a sociální dimenzí udržitelného rozvoje. Pod hlavičkou UNEP se sjednávají důležité mezinárodní smlouvy v oblasti životního prostředí. (2)

\subsection{World Water Assessment Programme (WWAP) - Světový program hodnocení vod podle OSN (WWAP)}

Tento program spravuje a řídí světová organizace UNESCO. Program koordinuje práci 31 členských států OSN a partnerů ve „Světové zprávě o rozvoji vody“ (WWDR; World Water Development Report). Tento každoroční přehled nám dává rozhodující obraz o stavu, využívání a řízení světových zdrojů sladké vody.

Kromě zpracovávání tohoto dokumentu WWAP mimo jiné monitoruje problematiku sladkých vod, poskytuje doporučení, vypracovává případové studie, posiluje hodnoticí kapacity na národní úrovni a informuje o výsledcích a rozhodnutích. (3)

\section{Opatření ve vybraných zemích}

\subsection{USA}

Federace Spojených států amerických je v oblasti podpory hospodaření s deštovými vodami velmi aktivní a houževnatá. V dohledu nad jednotlivými státy však hraje velkou roli politické uspořádání, protože spolkové státy mají svou vlastní vnitřní politiku a je komplikované do ní zasahovat.

\subsubsection{EPA - United States Environmental Protection Agency, Agentura pro ochranu životního prostředí}

EPA je americká federální agentura, jejíž rozpočet je určován federální vládou Spojených států.

Organizace EPA vznikla v důsledku zvýšeného zájmu o znečištování životního 
prostředí. Byla založena 2. prosince 1970, aby v rámci jedné organizace koncentrovala všechny snahy o federální výzkum, sledování potenciálních hrozeb, tvorbu norem a prosazování činností k zajištění ochrany životního prostředí. Posláním EPA je v zásadě ochrana lidského zdraví a životního prostředí.

EPA určuje strategie a dosažitelné cíle. Zároveň prověruje plnění těchto plánů a vydává dílčí a výroční zprávy. Přitom podává doporučení, jakými zpơsoby uplatňovat dostupné metody a přispívat ke zlepšení životního prostředí.

Při provádění samotném však EPA jako vládní organizace spolupracuje s WE\&RF (Water Environment \& Reuse Foundation), což je společnost, která se zabývá jednotlivými dílčími programy pro ochranu vodního prostředí. (4)

\subsubsection{Státy USA}

V posledních letech i USA pocitují výrazné sucho a dlouhá období bez srážek v mnoha svých lokalitách. Tento fakt se stává katalyzátorem legislativních kroků k legalizaci a podpoře jímání a využívání deštové vody v domácnostech a na pozemcích. Nová legislativní opatření se zaměřují na definování podmínek akumulace a užínání srážkové vody.

Například Texas a Ohio patři mezi státy, které věnovaly problému hospodaření $s$ deštovými vodami velkou pozornost a přijaly řadu zákonů, které regulují jímání a využívání deštové vody. Státy Rhode Island, Texas a Virginie zase poskytují daňové kredity nebo osvobození od daně z nákupu vybavení pro jímání deštové vody. Texas a Ohio dovolují použití deštových vod i ke konzumaci (pouze za předpokladu přečištění), což je často vyloučeno z právních a regulačních předpisů jiných států. V Oklahomě byl v roce 2012 schválen zákon o vodě pro rok 2060, který podporuje zejména pilotní projekty týkající se využívání deštové vody a šedé vody.

Západní státy USA už od nepaměti bojují s nedostatkem vody. Proto v nich byl zaveden zvláštní režim přerozdělování vody. Tento státem řízený proces hospodaření s vodními zásobami se nejvíce propisuje do legislativy v Coloradu a Kalifornii. V ostatních západních státech není tak striktní.

Tento systém předběžných prostředků je označován jako first in time, first in right. (5) Podle této zásady mají jednotlivci povinnost poskytnout vodu, která se pak přiděluje na základě priority uživatele. Za použití zdroje vody osobou, která tuto prioritu nemá, jsou stanoveny sankce. Tento systém však stále prochází legislativními změnami a je aktualizován. 


\subsection{Austrálie}

Historický vývoj HDV v Austrálii se velmi liší od vývoje HDV v ostatních zemích a na ostatních kontinentech. Zdejší civilizace si udržela tradici jímání deštové vody. Místní suché klima doslova vyžaduje zachování a zhodnocení každé kapky vody. Obyvatelé ani legislativa nijak neomezovali soukromé snahy o HDV, jako tomu je u některých států USA (z bezpečnostního a zdravotního hlediska).

Austrálie se tedy více než prosazováním HDV do legislativy zabývá jeho praktickými, bezpečnějšími a účinnějšími strategiemi.

\subsubsection{NWC - National Water Commission, Národní komise pro vodu}

Tato australská vládní organizace se zabývala vydáváním norem a prováděním legislativních kroků v rámci HDV, dokud nebyl v červnu 2015 schválen zákon o zrušení Národní vodní komise, kterým byla formálně zrušena. Její úlohu převzala Komise pro produktivitu, meteorologický úřad a australský úřad pro ekonomiku a vědu o zemědělství a zdrojích. Dnes tedy funguje NWC jen jako informační instituce. (6)

\subsubsection{RHAA - Rainwater Harvesting Association of Australia, Austral- ská asociace pro hospodaření s deštovou vodou}

Tato asociace je výkonným a poradním orgánem pro hospodaření s deštovými vodami v Austrálii. Konkrétně se zabývá poradenstvím, technickými řešeními či návody na instalaci, poskytuje výpočty pro objemy akumulačních nádrží, pořádá edukační akce pro vzdělávání veřejnosti, iniciuje pilotní projekty s ukázkami HDV, dohlíží na dodržování norem a legislativních předpisů. (7)

\section{Závěr}

Dostatek sladké vody není všude na světě samozřejmostí, proto státy, které trápí její nedostatek, začaly nejen primárně rozvíjet legislativní a finanční počiny a začaly řešit i technické metody systémů HDV.

Vzhledem ke globálním změnám a světovým prognózám vývoje klimatu na Zemi by se zdroji sladké vody měla nakládat hospodárně i střední Evropa.

Výše psaný text poukazuje na odlišné prúistupy států a organizací k šíření povědomí o hospodaření s deštovými vodami a na odlišné způsoby šíření povědomí. Některé země mohou být bohatým inspiračním zdrojem pro ostatní státy. Především pro 
ty, u kterých se legislativní a společenské osvojení principů hospodárného nakládání s př́rodními zdroji ještě neprojevilo.

Příspěvek vznikl ve vazbě na výzkumný projekt FA-S-16-3727 - 100. výročí vzdělávání architektů na Fakultě architektury VUT v Brně, oblast urbanismus.

\section{Zkratky}

EPA United States Environmental Protection Agency (Agentura na ochranu životního prostředí Spojených států)

IPCC The International Panel on Climate Change (mezinárodní platforma změny klimatu)

HDV hospodaření $s$ deštovými vodami, respektive RWH (Rainwater Harvesting)

NWC National Water Commission (Národní komise pro vodu)

$\mathrm{ODH} \quad$ Ohio Department of Health (ministerstvo zdravotnictví v Ohiu)

OSN Organizace spojených národů

RHAA Rainwater Harvesting Association of Australia (Australská asociace pro hospodaření s deštovou vodou)

UNEP United Nations Environment Programme (Program OSN pro životní prostředí)

UNESCO United Nations Educational, Scientific and Cultural Organization (Organizace OSN pro vzdělání, vědu a kulturu)

We \& RF Water Environment \& Reuse Foundation (Vodní prostředí \& Fond opětovného použití)

WWDR World Water Development Report of the UN (Světové zprávy o rozvoji vody OSN)

\section{Prameny}

1. Rainwater harvesting and utilisation: An Environmentally Sound Approach for Sustainable Urban Water Management; An Introductory Guide for Decision-makers [online]. Sumida City Government, 2002, IETC Urban Environment Series [2] [cit. 2017-08-20]. Dostupné z: http://www.unep.or.jp/ietc/publications/urban/ urbanenv-2/9.asp

2. Program OSN pro životní prostředí (UNEP) [online]. [cit. 2017-08-20]. Dostupné z: https://www.mzp.cz/cz/program_osn_pro_zivotni_prostredi_unep 
3. World Water Assessment Programme (WWAP) [online]. [cit. 2017-08-26]. Dostupné z: http://www.unesco.org/new/en/natural-sciences/environment/water/ wwap/about/

4. U.S. Environmental Protection Agency [online]. [cit. 2017-08-26]. Dostupné z: https://www.epa.gov

5. Prior Appropriation Law. COLORADO Division of Water Resources: Department of Natural Resources [online]. [cit. 2017-08-26]. Dostupné z: http://water.state. co.us/surfacewater/swrights/pages/priorapprop.aspx

6. National Water Commission (Abolition) Act 2015. In: National Library of Australia, AUSTRALIAN GOVERNMENT WEB ARCHIVE. National Water Commission, 2015. Dostupné také z: http://webarchive.nla.gov.au/gov/20160615060431/ http://nwc.gov.au

7. Rainwater Harvesting Association of Australia [online]. [cit. 2017-08-26]. Dostupné z: https://www.rainwaterharvesting.org.au

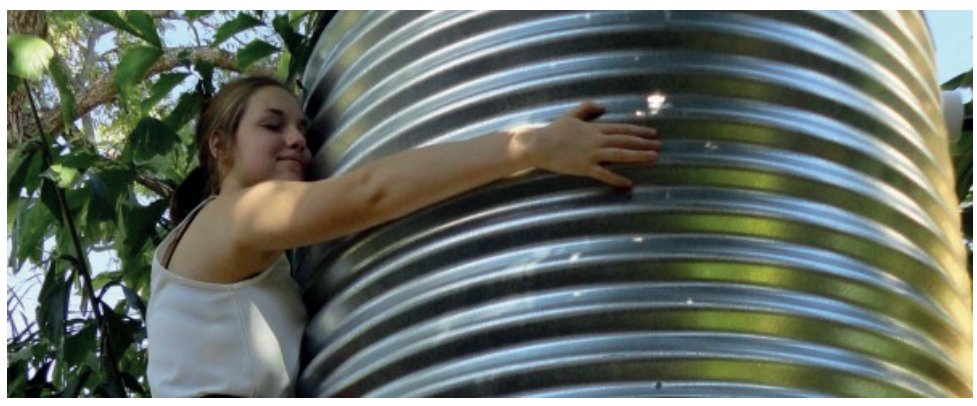

Obr. 1. Záchytné barely pro jímání deštové vody jsou v Austrálii běžnou součástí rodinných domů (Zdroj: Michael Smit; http://blog.rainwaterharvesting.org.au) 